\title{
Implications of Fraud on Commercial Banks Performance in Nigeria
}

\author{
Nwankwo, Odi. ${ }^{1}$ \\ ${ }^{1}$ Department of Banking and Finance, Kogi State University, Anyigba Kogi, Nigeria \\ Correspondence: Nwankwo, Odi., Department of Banking and Finance, Kogi State University, Anyigba Kogi, \\ Nigeria. Tel: 080-3576-3229. E-mail: odinwankwo2002@yahoo.com
}

Received: March 21, 2013

Accepted: April 7, 2013

Online Published: July 12, 2013

doi:10.5539/ijbm.v8n15p144

URL: http://dx.doi.org/10.5539/ijbm.v8n15p144

\begin{abstract}
Fraud is a global phenomenon that has been in existence for long and it increases every day by day. This study is set at evaluating the impact of fraud on the performance of commercial banks in Nigeria. It also sought to ascertain the relationship between bank ATM Fraud, Forged Cheque, Clearing Cheque Fraud and bank performance. The methodology adopted in testing objective of this study was regression analysis. The outcome of the research revealed that there is significant impact of fraud on the performance of commercial banks in Nigeria. The implication of this is that if the level of fraud in commercial bank did not reduced to the baerest minimum, it may not allow commercial banks to perform well and as well contribute to the growth of Nigeria economy. We recommend that there is an urgent need for effective monitoring of bank fraud through the use of ATM to allow for the growth of Nigeria commercial banks performance. This is necessary especially this period that the world is going cashless and ATM is the main instrument for cashless banking system of payment.
\end{abstract}

Keywords: bank fraud, ATM fraud, forged cheque fraud, clearing fraud, bank performance

\section{Introduction}

Fraud is a global phenomenon that has been in existence for long and it increases everyday by day. Fraud is a deliberate act that causes a business or economy to suffer damages, often in the form of monetary losses. Fraud is rampant in both developed and developing countries and as well varies across places in its magnitude, its sources, the way it manifests itself and in its effects on administrative performance and development. Olufidipe (1994) defined fraud as "Deceit or trickery deliberately practiced in other to gain some advantage dishonesty." Oxford Advanced Learner's Dictionary defined fraud as the crime of cheating somebody in order to get money or goods illegally. It is also a person who pretends to have qualities, abilities etc. that they do not really have in order to cheat other people. Alashi, (1994) opined that fraud means an act of dishonesty, deceit and imposture. According to Kirkpatrick (1995), "a person who pretends to be something that he is not is a fraud, a snare, a deceptive, trick, cheat and a swindler. By extension fraud will include embezzlement, theft or any attempt to steal or unlawful obtain, misuse or harm the assets of bank (Nzotta, 1999). Fraud according to Adeniji (2004) and ICAN (2006) is an intentional act by one or more individuals among management, employees or third parties which results in a misrepresentation of financial statement.

Financial reforms in Nigeria have evolved various strategies to encourage financial intermediation and mobilization of savings for investment which promote economic growth and development (Egwu, 2012). These reforms seek to act proactively to strengthen the market mechanism, remove systematic and financial crisis, ensure a more liberal financial system and increase reduction of fraud. Fraud in banking industry is a global phenomena and its growth in Nigeria economy has been astounding. Fraud is the number one enemy of business growth world over. The fear now is that the increase rate of fraud in the financial institutions, if not arrested mighty pose certain threats to the stability and the survival of individual financial institution and the performance of the industry as a whole and no area of the economy is immune from fraudsters (Nwankwo, 2005). Bank frauds is generally bringing untold hardship on bank owners, staff, customers and family members as most bank failures are always associated with large scale of frauds (Okoro, 2003).

Fraud in bank shakes the foundation and credibility of most banks in Nigeria resulting to some of the bank being distressed. The study is faced with challenges to uncover the problem of how fraud affect the performance of Nigerian banking industry and economy in general considering the positive or negative effect based on the present nature of Nigerian banking industry. Hence, it is against this background that this study meant to investigate the implication of fraud on commercial bank performance in Nigeria. 
This paper is organized as follows; section one is the introduction while section two reviews the empirical and theoretical literature on fraud and it effect on commercial banks in Nigeria; section three discusses the models and methodology while section four provides data and empirical evidence and the final section which is section five provides the summary, conclusion and recommendations of the study.

\section{Review of Related Literature}

\subsection{Theoretical Framework}

Attempts have been made to weave the factors that affect fraud into comprehensive theories of fraud and animal behaviour theories of fraud. Babatunde (2009) posits that motivation to fraudulent behaviour derives from number of causes. It could be pathological or greed. Pathological theory states that culture demands on the cultivation of taste too expensive for the legitimate income of the individual criminal motivation with particular reference to fraud and when the state of mind of the criminal disposes and impels him to commit fraud, even though he/she is not in due need of the resources.

Greed theory of fraud states that banks have become persistent targets of men of the underworld mainly because bank are seen as the richest organisation in the country. The theory goes further to enumerate some of the causes of fraud as instable instinct for wealth over concentration of authority, poor security arrangements for sensitive documents and so on (El-Haddan and Almahmeed, 1999). The development of fraudulent behaviour can be traced to middle childhood when moral behaviour start. Kohlber (2008) in his book called theory of moral development explained that conventional level of morality develops between the ages of 10-16years. He states that this is the stage during which a child learns to understand the rules, differentiating wrong from right actions to accept and respect authority and to abide by societal rules in order to win the approval of others.

Nweze (2008) grouped the major causes of bank fraud into two: Institutional factors and Environmental factors.

Institutional factors or causes are those that can be traced to internal environment of the financial institution. They are as follows:

1) Inadequate Infrastructure: Poor communication systems and power failure result to ATM bank fraud which encourages the perpetration of fraud in banks.

2) Nature of Service: Fraud may be caused where documents of value and liquid assets are exposed to an undisciplined staff or unauthorized person(s) like customer(s) in the bank.

3) Poor Management: This comes in form of inadequate supervision. A junior staff with fraudulent tendencies that is not adequately supervised would get the impression that the environment is safe for the perpetration of fraud especially ATM.

4) Poor Security Arrangement: Banks security arrangement for valuable documents are weak, poor and vulnerable, it is easy for fraudsters to have their ways undirected in the bank.

5) Poor Salaries: Employees that are poorly paid are often tempted to fraudulently convent some of the customer's monies to their own use in order to meet their personal and social needs. This temptation is stronger on bank employees who are on daily basis have to deal with cash and near cash instruments.

6) Frustration: This is a place where a staff feels short-changes in terms of promotion and other financial reward, they became frustrated and such frustration could lead to fraud as much as such employee would attempt to compensate himself in his own way and it is an indication of weakness in bank internal control system.

Environmental Factors: These are those factors that can be traced to the banks immediate and remote environment (Nweze, 2008).

1) Unemployment and High level of Poverty in Nigeria: Nigeria is one of the richest economics in sub-Sharan African and indeed the world both in human and natural resources (Oil), but $80 \%$ of the Nigeria youths especially university graduates are unemployed. Most of the politicians squirt away the looted funds in foreign banks without been punished by the EFCC. This causes unemployment and lack of infrastructure which is not good for a developing country like ours. Because of over stayed after graduation, directly or indirectly, some Nigeria youths especially those that find themselves in the banking industry with criminal intent engage in one bank fraud or the other with the aim of eradicating poverty.

2) Fear of Negative Publicity: Many financial institutions fail to report fraud cases to the appropriate authorities. They believed that doing so will give unnecessary negative publicity about the bank and it is a chance for fraudsters to thrive because it is a great challenge to a researcher as regards to data collection. 
3) Societal Value: When the possession of weakness determines the reputation ascribed to a person, that society is bound to witness unnecessary competition for acquisition of wealth. The desire to be with the high and mighty calibre of the society, extreme want that is often characterized by need and cultivation of a life too expensive for the legitimate income of the individual which to a large extent encourages bank fraud.

\subsection{Empirical Review}

There have been an extensive studies conducted in many countries on fraud and it's effect on bank performance. In a study conducted by Wole and Couisa (2009) tested the attributes of the theory of diffusion of innovation empirically, using automated teller machines (ATMs) as the target innovation. The study found that attitudinal dispositions significantly influence the use of ATM in any bank and thereby affecting the performance of the bank. Adewunmi (2007) in his explanation of bank fraud identify socio-economic lapse in society such as misplacement of societal values, the unquestioning attitude of society towards the sources of wealth, the rising societal expectations from bank staff and the subsequent desire of the staff to live up to such explanations as contributory factors of fraud. Akinfala (2005) conduct a research on job involvement/ experience factors and fraudulent behaviors among serving and convicted bank staffs. The study found that the level of job involvement has function of three factors: motivation, identification and a feeling of pride that people achieve in their jobs. Nwude (2006) carried out a bank frauds using methodology of an interaction with bank staff of various cadres with structured questionnaire to identify the fraud forms and characteristics in the banking industry. The study reveals that some staff involve in fraud due to greediness and arrogance.

In a different study, Otusanya (2008) carried out a study on the role of Bank CEO in the perpetration of corporate executive frauds in the Nigerian Banking sector. The study reveals that recent banking crises in Nigeria have exposed the activities of bank executives in corruption and fraudulent practices using institutional anomie theory called American dream theory, whereby the pursuit of monetary success has come to dominate society.

Idowu (2009) did a research on the means of minimizing the incidence of fraud in Nigerian banking industry. Findings of the study revealed that, so many factors contributed to the incidence of frauds in banks amongst which are poor management of policies and procedures, inadequate working conditions, bank staff staying longer on a particular job and staff feeling frustrated as a result of poor remunerations. Adepoju and Alhassan (2010) opined that bank customers have come to depend on and trust the Automatic teller machine (ATM) to conveniently meet their banking needs, but that in recent times; there have been a proliferation of ATM frauds in the country. Managing the risks associated with ATM fraud as well as diminishing its impact is an important issue that face banks as fraud techniques have become more advanced with increased occurrences. Akindele (2010) conducted a research on the "challenges of automated teller machine (ATM) usage and fraud occurrence in Nigeria banking industry". The study posits that lack of adequate training, communication gap, and poor leadership skills were the greatest causes of fraud in banks. He advised that adequate internal control mechanism be put in place and that workers satisfaction and comfort be taking care of.

Onuorah and Ebimobowei (2011) investigate fraudulent activities and forensic accounting in Nigeria. The study found that there is need for the banks in Nigeria to adopt more proactive measures such as the use of forensic accounting techniques in banks.

Abdulrasheed, Babaitu and Yinusa (2012) examined the impact of fraud on bank performance in Nigeria. Result of the study shows that, there is a significant relationship between banks profit and total amount of funds involved in fraud. Finally, Kanu and Okorafor (2013) did a work on the nature, extent and economic impact of fraud on bank deposit in Nigeria using descriptive and inference statistics. The study revealed that there is a positive significant relationship between bank deposit and fraud in Nigerian banking industry.

\section{Research Methodology}

The study used quantitative research design and a set of regression estimates was applied to test the level of significance of the study between fraud and bank performance in Nigeria. Bank performance was proxied by earning per share of the First Bank Plc which measures the level of bank performance and its contribution to the economy and as well serve as the dependent variable. The independent variables are clearing fraud: this is the bank clearing fraud that occurs in the process of cheque clearing in the bank; ATM fraud which is been measured by the level of fraud through the use of ATM in the banking industry; and forged cheque fraud, this type of fraud refers to a category of criminal acts that involve making the unlawful use of cheques in order to illegally acquire or borrow funds that do not exist within the account balance or account-holder's legal ownership. Secondary data where generated from the NSE Factbook, NDIC and CBN publications for the 
period of 2001-2011. This type of design were used by similar study conducted by Adewumi (2007), Akindele (2010), Onuorah and Ebimobowei (2011) and Kanu and Okorafor (2013). Given the design nature of this study, bank performance (earning per share) were used as dependent variable while, ATM fraud, forged cheque and clearing fraud as proxied by bank fraud were used as the independent variable.

Hypotheses

$\mathrm{H}_{01}$ : There is no significant positive relationship between ATM bank fraud and the bank performance in Nigeria.

$\mathrm{H}_{02}$ : There is no significant positive relationship between forged cheque fraud and the performance Nigerian banking industry.

$\mathrm{H}_{03}$ : There is no significant positive relationship between clearing bank fraud and the performance Nigerian banking industry.

\section{Results and Discussion}

\subsection{Descriptive Results}

This section is concerned with the presentation, analysis and interpretation of data which were collected in the course of doing this work during the period 2001-2011. Descriptive and analytical tools were conducted on the variables selected. The descriptive tests include Augmented Dickey Fuller (ADF) unit root test and cointegration tests.

\subsection{Unit Root Test}

The results of the ADF unit-root test in table 1.1 below confirm that the following variables are stationary at first $\left(1^{\text {st }}\right)$ differencing i.e they are $1(1)$ :

1) Earning Per Share (EPS).

2) ATM Bank Fraud (ABF).

3) Forged Cheque (FC).

4) Clearing Fraud (CF).

The stationarity test was judged by the maximum Eigenvalue @ $5 \%$ and 10\% critical values.

Table 1. ADF unit root test for stationarity

\begin{tabular}{cccccc}
\hline Variables & T. statistics & Critical levels: $1 \%$ & $5 \%$ & $10 \%$ & Decision \\
\hline EPS & 1.860899 & -4.297073 & -3.212 & -2.748 & $1(1)$ \\
ABF & 2.889020 & -4.420595 & -3.260 & -2.771 & $1(1)$ \\
FC & 1.154928 & -4.297073 & -3.213 & -2.748 & $1(1)$ \\
CF & 1.506731 & -4.297073 & -3.213 & -2.748 & $1(1)$ \\
\hline
\end{tabular}

Note: All variable stationary at first differencing.

\subsection{Co-Integration Tests}

The Johansen co-integration test was conducted on the selected variables. The results obtained from the above unit root test confirm that all the variables are integrated of order one. On the basis of the above unit-root tests result, we apply the Johansen co-integration tests. The results are presented below:

Table 2. Co-integration test results

\begin{tabular}{ccccc}
\hline Hypotheses & Eigenvalue & T. statistics & 0.05 Critical Value & Probability \\
\hline None* & 0.923778 & 16.4698 & 95.75366 & 0.000 \\
At most 1* & 0.805363 & 101.1171 & 69.81889 & 0.000 \\
At most 2* & 0.660859 & 60.20159 & 47.85613 & 0.0023 \\
At most 3* & 0.586713 & 33.18286 & 29.79707 & 0.0196 \\
\hline
\end{tabular}

$*^{*}$ ) denotes rejection of the hypothesis at $5 \%$ significance level; The test indicates 4 co-integration equation(s) at $5 \%$ significance level. 


\subsection{Presentation of OLS Results}

As a co-integration relationship has been established among the variables, and then OLS model can be estimated to determine the effect of bank fraud on the performance of Nigerian banking industry. The analytical tool used is a regression analysis which depends on the correlation between dependent and independent variables.

Variable $(Y)$ as a function of one variable $(X)$. That is, $K_{t}=f\left(K_{t-1}\right)$. $Y$ is equal to $K_{t}$ which is the earning per share and $\mathrm{X}$ is the $\mathrm{K}_{\mathrm{t}-1}$ which is the independent variables in the form of regression equation.

$\mathrm{Y}=\beta_{0}+\beta_{1} \mathrm{X}+\mu$

$\mathrm{Y}=\mathrm{EPS}$ and $\mathrm{X}=$ Fraud Variables

$\beta_{0}=$ Constant Term

$\beta_{1}=$ Coefficient of $X_{1}$

$\mu=$ Error Term

Table 3. Presentation of OLS results

\begin{tabular}{|c|c|c|c|c|}
\hline \multicolumn{5}{|l|}{ Dependent Variable: EPS } \\
\hline \multicolumn{5}{|l|}{ Method: Least Squares } \\
\hline \multicolumn{5}{|l|}{ Sample: 20012011} \\
\hline \multicolumn{5}{|l|}{ Included observations: 11} \\
\hline Variable & Coefficient & Std. Error & t-Statistic & Prob. \\
\hline $\mathrm{C}$ & 436863.7 & 40712.65 & 10.73042 & 0.0000 \\
\hline $\mathrm{ABF}$ & -1148.098 & 2503.114 & -0.458668 & 0.0000 \\
\hline $\mathrm{FC}$ & -0.153618 & 0.028229 & -5.441817 & 0.0010 \\
\hline $\mathrm{CF}$ & 4848.487 & 812.7181 & 5.965768 & 0.0006 \\
\hline ECM & -0.786543 & 23.58639 & 3.862197 & 0.0000 \\
\hline R-squared & 0.839222 & ent var & & 480868.9 \\
\hline Adjusted R-squared & 0.770317 & nt var & & 154911.9 \\
\hline S.E. of regression & 74241.84 & riterion & & 25.54333 \\
\hline Sum squared resid & $3.86 \mathrm{E}+10 \mathrm{~b}$ & erion & & 25.68802 \\
\hline Log likelihood & -136.4883 & n criter & & 25.45212 \\
\hline F-statistic & 12.17945 & on stat & & 2.124952 \\
\hline Prob(F-statistic) & 0.003629 & & & \\
\hline
\end{tabular}

\section{Test of hypothesis 1}

The regression coefficient of ABF is -1148.098 and its P-value is 0.0000 . Since the P-value $(0.0000)<0.05(5 \%$ level of significance), we reject the null hypothesis and conclude that there is significant negative relationship between ATM bank fraud and the bank performance in Nigeria.

\section{Test of hypothesis 2}

The regression coefficient of FC is -0.153618 and its P-value is 0.0010 . Since the P-value $(0.0000)<0.05(5 \%$ level of significance), we reject the null hypothesis and conclude that there is significant negative relationship between forged cheque fraud and the bank performance in Nigeria.

\section{Test of hypothesis 3}

The regression coefficient of CF is 4848.487 and its P-value is 0.0006 . Since the P-value $(0.0000)<0.05(5 \%$ level of significance), we reject the null hypothesis and conclude that there is significant and positive relationship between clearing fraud and the bank performance in Nigeria.

\subsection{Discussion of Findings}

The sub-section 4.4 above shows the over parameterized over error correction of bank fraud and performance of deposit money banks in Nigeria using first bank Plc as a focus. The ECM is positive as theory predicts, and the value indicates that about $78.6 \%$ error corrections take place in the model. Also, the $\mathrm{R}^{2}$ is 0.83 or $83 \%$ with the Durbin Watson of 2.124. It could be deduced from the results that all the probabilities for the variables are less than $5 \%$. Therefore, there is no need to go further to the parsimonious error correction model (ECM2).

From the over-parameterized model result above, it can be seen that the co-efficient of ATM bank fraud, Forged 
Cheque fraud and Clearing Fraud are in conformity with the 'a priori' expectations. There is a positive relationship between Performance of Banking Industry and Clearing Cheque Fraud with the co-efficient of Clearing Cheque fraud at 4848. 487, this implies that a unit increase in CF will increase all EPS by 4848.487. Again, the co-efficient of ATM fraud and Forged cheque fraud are negative in conformity with our ' $a$ priori' expectations. This means that there is a negative relationship between EPS, ABf and FC. The co-efficient of $\mathrm{ABF}$ and $\mathrm{FC}$ are -1148.098 and -0.153618 respectively, meaning that a unit increase in $\mathrm{ABF}$ and $\mathrm{FC}$ will lead to 1148.098 and -0.153618 unit decrease in ESP. More so, the ECM otherwise known as the speed of adjustment is significant with the appropriate sign i.e. negative sign in conformity with the 'a priori' expectation. This means that the present value of EPS adjust to changes in ATM bank fraud (ABF), Forged cheque fraud (FC), and Clearing cheque fraud (CF). The large value of the error correction variable given as $78.65 \%$ indicates a feedback of that value or the adjustment of that value from the previous period disequilibrium of the present level of EPS in the determination of the causality between the past level of EPS and the present and past level of $\mathrm{ABF}, \mathrm{FC}$ and $\mathrm{CF}$.

The co-efficient of determination $\left(\mathrm{R}^{2}\right)$ shows the percentage total of variation in the dependent variable explained by the independent variable. The $\mathrm{R}^{2}$ from the model stands at 0.8392 or $83.92 \%$. This means that over $83 \%$ of the variation in the present state of performance of Nigerian banking industry is being explained by the past values of EPS and the present and past values of $\mathrm{ABF}, \mathrm{FC}$ and $\mathrm{CF}$ while $17 \%$ of the variation in the present value of EPS is being explained by the stochastic error term. Therefore, F-Tabulated $=3.24$ and F-Calculated $=$ 12.17945 (obtain from computer output above). Since the F-calculated is greater than F-tabulated, the null hypothesis is rejected while the alternative hypothesis is accepted. This shows the overall significance of the model.

Based on the above analysis, three empirical results were found; from the first test or variable, ATM bank fraud appeared in our regression test with significant and negative relationship. Judging from this, we can agree that there is significant negative relationship between ATM bank fraud and the performance of Nigerian banking industry; the second test indicates that the variable forged cheque appeared in our model result with negative sign and as well significant. Based on this result, we agree with a conclusion that there is significant negative relationship between forged cheque fraud and performance of commercial banks in Nigeria; and the third one indicates that the variable clearing fraud appeared with positive sign. The p-value of 0.0006 under 0.05 level of significance shows a strong significance level between clearing cheque fraud and performance of commercial banks in Nigeria. This means that there is significant positive relationship between the level of clearing fraud and performance of Nigerian commercial banks.

\section{Conclusion and Recommendations}

\subsection{Conclusion}

Based on the research findings, it can be inferred that it is important to emphasize that the management and regulation of bank fraud was quantitatively important in the performance of Nigerian commercial banks. We observed that bank fraud whether through electronic device, clearing or cheque has had a positive effect on the performance of commercial banks in Nigeria. This is because the results obtained from this study support both theoretical and empirical evidence that bank fraud have a great implication on the performance of Nigerian commercial banks and concluded that the level of ATM bank fraud over the years have indeed negatively affected insignificantly on performance of commercial banks in Nigeria; that forged cheque has negative effect but significant on the performance of commercial banks in Nigeria; and that there is significant positive relationship between clearing fraud and the level of commercial banks performance in Nigeria.

\subsection{Recommendations}

From the finding of this study, the following recommendations were made to improve the implication of bank fraud on performance of commercial banks in Nigeria.

There is an urgent need for effective monitoring of bank fraud through the use of ATM to allow for the growth of Nigeria commercial banks performance. This is necessary especially this period that the world is going cashless and ATM is the main instrument for cashless banking system of payment.

We also recommended that the forged cheque be strengthened through effective supervision and regulation of loan in financial system by the monetary authorities so that financial industry will contribute to the economy.

There should be consistence in banking regulation in Nigeria. This is to ensure adequate performance of Nigerian banking industry and its contribution to the growth of Nigerian economy as a whole.

There should be social value among bank staffs and their. 
Finally, there is need for further management of clearing fraud in Nigeria to allow for more chance of economic growth in the country through commercial bank contribution.

\section{References}

Abdul Rasheed, S., Babaitu, D., \& Tinusa, G. (2012). Fraud and its implications for bank performance in Nigeria. International Journal of Asian Social Science, 2(4), 35-45.

Ademola, A. (2001). Fraud in banks: the Nigerian perspective Expert edge Software. Seminar on fighting fraud with technology: solutions to Nigerian banks.

Adeniji, A. (2004). Auditing and investigation. Lagos: Landmark Publisher.

Adepoju, A., \& Alhassan, G. (2010). Challenges of automated teller machine (ATM) usage and fraud occurrence in Nigeria-A case study of selected banks in Minna Metropolis. Journal of Internet Banking and Commerce (JIBC), 15(2), 2-10.

Adewumi, S. (2011). An Ideal ATM Implementation in an Unsecured Environment. University of Jos Press.

Adewunmi, W. (Ed.). (1986). Fraud in banks-An overview. Land marks publications: Lagos.

Adewunnmi, W. (2007). Fraud in bank, Nigeria Institute of Bankers. Landmark publication, Lagos.

Akindele, R. I. (2011). Fraud as a negative catalyst in the Nigerian banking industry Journal of Emerging Trends in Economics and management Sciences (JETEMS). Bank administration institute of America and First National bank of Chicago: Fraud prevention series. Benson and Edwards fraud prevention series (Volumes 1-11). B \& E publishers Lagos.

Babatunde, G. (2009). Precipitating factors in fraud and criminal motivation. International Journal of Bank Marketing, 10(3), 232-250.

Idowu, A. (2009). An assessment of fraud and its management in Nigeria commercial banks. European Journal of Social Sciences, 10(4).

Iyiegbuniwe, W. (1998). Fraud Risk in Nigerian Banks. Unilag Journal of Business, 1(2).

Kanu, S. I., \& Okoroafor, E. O. (2013). The Nature, Extent and Economic Impact of Fraud on Bank Deposit in Nigeria. Interdisciplinary Journal of Contemporary Research in Business, 4(9), 253-264.

NDIC. (2011). Annual Report and statement of Account.

Nwaeze, C. (2008). Quality and Internal Control Challenges in Contemporary Nigeria Banking. Zenith Economic Quarterly, Zenith Bank PLC, 3(2), 23-28.

Nwankwo, G. O. (2005). Bank Management Principles and Practices. Malthouse Press Ltd: Lagos-Nigeria.

Nweze, C. (2008). Bank fraud exposed with cases and preventive measures. Control \& surveillance associates limited, Lagos.

Ogunleye, G. A. (2007). Proactive Measures to guard against fraud/cash theft in the banking industry and in organizations. NDIC Quarterly, 17(3/4).

Ogunleye, G. A. (2004). The causes of Bank Failures and persistent distress in the Banking Industry. NDIC Quarterly, 13(4).

Ogunleye, G. A. (2010). Perspectives on the Nigerian Financial safety-Net Nigeria Deposit insurance corporation, Abuja.

Okoro, G. (2003). An Investigation of Fraud in Banks. An Unpublished Thesis of University of Lagos.

Onuorah, S., \& Ebimobowei, D. (2012). Fraudulent activities and forensic accounting services of banks in Port Harcourt, Nigeria. Asian Journal of Business Management, 4(2).

Otusanya, J. O. (2009). An investigation of corporate executive fraud by CEOs in the Nigerian banking industry. A seminar paper presented at the Department of Accounting, faculty of business Administration, University of Lagos.

\section{Copyrights}

Copyright for this article is retained by the author(s), with first publication rights granted to the journal.

This is an open-access article distributed under the terms and conditions of the Creative Commons Attribution license (http://creativecommons.org/licenses/by/3.0/). 